Natalia Jarska

https://orcid.org/0000-0002-5321-768X

Instytut Historii im. Tadeusza Manteuffla Polskiej Akademii Nauk

\title{
Praca zawodowa kobiet a relacje małżeńskie w powojennej Polsce. Analiza materiałów konkursów pamiętnikarskich z lat 1963, 1964 i 1974*
}

Zarys treści: Artykuł omawia wpływ pracy zawodowej kobiet na stosunki w małżeństwie. Podstawą źródłową analizy są oryginalne pamiętniki konkursowe pochodzące $\mathrm{z}$ trzech konkursów $\mathrm{z}$ lat 1964, 1965 i 1974. W artykule stawiam tezę, że praca zawodowa, szczególnie związana z wykształceniem i pozycją zawodową, wpływała na podniesienie statusu kobiety w małżeństwie, choć była rozumiana jako drugorzędna. Innym czynnikiem wpływającym na zmianę pozycji kobiety w małżeństwie było upowszechnianie się partnerskiego modelu małżeństwa, co także pokazują omawiane pamiętniki.

Abstract: The article discusses the impact of women's work on relations in marriage. The source basis of the study are original personal memoirs written for three competitions organised in 1964, 1965 , and 1974. I argue that professional work, especially related to education and professional position, raised the status of women in marriage, even though the women's employment was regarded as of secondary importance. Another factor changing the role of women in marriage was the popularisation of the partnership model of marriage, which is also mirrored in the analysed.

Słowa kluczowe: kobiety, płeć kulturowa, praca zawodowa, małżeństwo, PRL

Keywords: women, gender, professional career, marriage, Polish People's Republic

Proces aktywizacji zawodowej kobiet w krajach państwowego socjalizmu doczekał się już sporej literatury, choć zazwyczaj analizowany był głównie w kontekście przemian pozycji kobiet w sferze publicznej i równości ekonomicznej, rzadziej w kontekście rodziny. Sytuacja w PRL była pod tym względem bardzo zbliżona do sytuacji w innych krajach tzw. demokracji ludowej. Historycy i historyczki

\footnotetext{
* Praca powstała w wyniku realizacji projektu badawczego o nr. 2016/21/D/HS3/02739, finansowanego ze środków Narodowego Centrum Nauki.
} 
opisywali zmieniającą się politykę wobec pracy zawodowej kobiet, analizowali propagandę i doświadczenia związane z pracą, edukacją i awansem ${ }^{1}$. Z jednej strony w literaturze przedmiotu wskazuje się na ważną rolę pracy zawodowej i edukacji dla wzmocnienia pozycji kobiet, z drugiej - na utrzymywanie się nierówności w sferze zawodowej. Często zwraca się uwagę na niedowartościowanie sfery domowej, jej zbyt mało dynamiczne przeobrażenia, pozostające $\mathrm{w}$ tyle za tempem wzrostu zatrudnienia kobiet. System socjalistyczny, jak argumentuje Susan Zimmermann, opierał się na pracy dwojga żywicieli i nieodpłatnej pracy domowej kobiet ${ }^{2}$. Sfera domowa, mimo początkowo rewolucyjnych haseł, była wciąż konceptualizowana jako kobieca ${ }^{3}$. Podobnie rodzicielstwo - macierzyństwo pozostało rolą, wokół której koncentrowały się oficjalne dyskursy i polityka wobec kobiet, szczególnie po okresie stalinowskim4. Od końca lat sześćdziesiątych większość krajów tzw. bloku socjalistycznego, w obawie przed kryzysem

${ }^{1}$ M.in.: M. Fidelis, Equality through Protection. The Politics of Women's Employment in Postwar Poland 1945-1956, „Slavic Review” 63, 2004, nr 2, s. 301-324; eadem, Women, Communism, and Industrialization in Postwar Poland, Cambridge 2010 (wyd. polskie: Kobiety, komunizm i industrializacja w powojennej Polsce, Warszawa 2015); W.Z. Goldman, Women at the Gates. Gender and Industry in Stalin's Russia, Cambridge 2002; F. de Haan, Women as the "motor of modern life". Women's work in Europe west and east since 1945, w: Women and Gender in Postwar Europe. From Cold War to European Union, eds. J. Regulska, B.G. Smith, London-New York 2012, s. 97-113; N. Jarska, Kobiety $z$ marmuru. Robotnice $w$ Polsce $w$ latach 1945-1960, Warszawa 2015; eadem, Gender and Labour in Post-War Communist Poland. Female Unemployment 1945-70, „Acta Poloniae Historica" 110, 2014, s. 49-85; D. Jarosz, Kobiety a praca zawodowa w Polsce w latach 19441956 (główne problemy w świetle nowych badań źródłowych), w: Kobieta i praca. Wiek XIX i XX, red. A. Szwarc, A. Żarnowska, Warszawa 2000, s. 217-241; K. Lebow, Unfinished Utopia. Nowa Huta, Stalinism, and Polish Society, 1949-56, Ithaca 2013; J. Massino, Constructing the Socialist Worker. Gender, Identity and Work under State Socialism in Braşov, Romania, „Aspasia. The International Yearbook of Central, Eastern, and Southeastern European Women's and Gender History" 3, 2009, s. 131-160; M. Mazurek, Społeczeństwo kolejki. O doświadczeniach niedoboru 1945-1989, Warszawa 2010; P. Perkowski, Aktywność zawodowa gospodyń domowych na łamach prasy kobiecej Polski Ludowej, w: Koniec mitu niewinności? Płeć i seksualność w socjalizacji i edukacji, red. L. Kopciewicz, E. Zierkiewicz, Warszawa 2009, s. 289-315; R. Podskarbi, Praca daje wyzwolenie. O nowej kobiecie w nowej Polsce, w: Społeczeństwo PRL. Historia. Kultura. Pamięć, t. 1: Historia, red. S. Jankowiak, D. Skotarczak, I. Skórzyńska, Poznań 2011, s. 261-269; E.Z. Tóth, „My Work, My Family, My Car": Women's Memories of Work, Consumerism, and Leisure in Socialist Hungary, w: Gender Politics and Everyday Life in State Socialist Eastern and Central Europe, eds. J. Massino, S. Penn, New York 2009, s. 33-44.

2 S. Zimmermann, Gender Regime and Gender Struggle in Hungarian State Socialism, „Aspasia. The International Yearbook of Central, Eastern, and Southeastern European Women's and Gender History" 4, 2010, s. 1-24.

${ }^{3}$ I. Asztalos Morell, How to Combine Motherhood and Wage Labour: Hungarian Expert Perspectives During the 1960s, w: Gender, Equality and Difference During and After State Socialism, ed. R. Kay, New York 2007, s. 41-62; D. Harsch, Revenge of the Domestic: Women, the Family, and Communism in the German Democratic Republic, Princeton 2007.

${ }^{4}$ L. Haney, From Proud Worker to Good Mother: Women, the State, and Regime Change in Hungary, „Frontiers. A Journal of Women Studies” 14, 1994, nr 3, s. 113-150. 
demograficznym, postawiła na politykę pronatalistyczną, w tym działania mające na celu pomoc w łączeniu pracy zawodowej $\mathrm{z}$ wychowaniem dzieci, dodatkowo wzmacniając przyporządkowanie do ról pełnionych w rodzinie ${ }^{5}$. W praktyce utożsamienie kobiet ze sferą domową, przy bardzo ograniczonych próbach redefinicji ról mężczyzn, utrudniało emancypację w sferze zawodowej.

Przeobrażenia rodziny są także szeroko badane. Państwa określane mianem demokracji ludowej przyjęły ustawodawstwo rodzinne, które było na owe czasy rewolucyjne: wprowadzono równość małżeńską, rozwody i śluby cywilne 6 . Nowoczesna rodzina socjalistyczna przedstawiana $\mathrm{w}$ dyskursach eksperckich i propagandzie miała opierać się na równości i odrzucić tradycyjny podział na męskiego żywiciela i kobietę przypisaną do sfery domowej (choć w praktyce przed II wojną światową tenże ideał miał ograniczony zasięg). Jak pokazują dynamicznie rozwijające się w ostatnim czasie badania nad dyskursami eksperckimi dotyczącymi małżeństwa, seksualności i planowania rodziny, pomimo głoszenia zasady równości płci i podważania tradycyjnych ról (szczególnie do połowy lat sześćdziesiątych) dyskursy te umacniały różnicę płci i ograniczały pozycję kobiet ${ }^{7}$. Analiza rzeczywistych stosunków rodzinnych i roli kobiet w tej sferze pokazuje, że zmiany były powolne, choć różne w zależności od kraju ${ }^{8}$. Trwałe małżeństwo i rodzina pozostawały celem polityki państwa jako czynniki stabilizacji. Rozwód, szczególnie w Polsce, nie upowszechnił się i nadal podlegał silnej stygmatyzacji ${ }^{9}$. Jak ciekawie pokazała Jill Massino, analizując relacje małżeńskie w Rumunii dochodziło do istotnych przeobrażeń w tej sferze, co wynikało tak z lansowania nowych wzorców rodziny, jak i z trudności ekonomicznych (np. mężczyźni byli

\footnotetext{
${ }^{5}$ U. Brunnbauer, K. Taylor, Creating a "socialist way of life": family and reproduction policies in Bulgaria, 1944-1989, „Continuity and Change” 19, 2004, s. 283-312; P. Perkowski, Wedded to Welfare? Working Mothers and the Welfare State in Communist Poland, „Slavic Review” 76, 2017, nr 2, s. $455-480$.

${ }^{6}$ Podsumowanie tych zmian zob.: K. Lišková, Sexual Liberation, Socialist Style: Communist Czechoslovakia and the Science of Desire, 1945-1989, Cambridge 2018.

${ }^{7}$ A. Kościańska, Płeć, przyjemność i przemoc. Kształtowanie wiedzy eksperckiej o seksualności w Polsce, Warszawa 2014; A. Ignaciuk, No Man's Land? Gendering Contraception in Family Planning Advice Literature in State-Socialist Poland (1950s-1980s), „Social History of Medicine” (cop.) 2019, preprint, s. 1-23; N. Jarska, Modern Marriage and the Culture of Sexuality: Experts between the State and the Church in Poland, 1956-1970, „European History Quarterly” 43, 2019, nr 3, s. 467-490; B. Klich-Kluczewska, Biopolitics and (Non-)Modernity. Population Micro-Policy, Expert Knowledge and Family in Late-Communist Poland, „Acta Poloniae Historica” 115, 2017, s. 151-174.

${ }^{8} \mathrm{Na}$ przykład dość głębokie przeobrażenia przechodziła rodzina w NRD, zob. J. McLellan, Love in the Time of Communism: Intimacy and Sexuality in the GDR, Cambridge 2011. Na temat polskiego kontekstu pisała przede wszystkim Barbara Klich-Kluczewska w książkach: Przez dziurkę od klucza. Życie prywatne w powojennym Krakowie, Warszawa 2005; Rodzina, tabu i komunizm w Polsce 1956-1989, Kraków 2015. Statystyczny obraz zmian przedstawił Andrzej Chojnowski w artykule Polska po Październiku '56. Przewodnik statystyczny po życiu rodzinnym, „Dzieje Najnowsze” 49, 2017, nr 3, s. 145-173. Przemiany małżeństwa w PRL omawiam w dalszej części artykułu.

${ }^{9}$ B. Klich-Kluczewska, Rodzina, tabu i komunizm..., rozdział 4.
} 
zmuszeni przejmować część obowiązków domowych z powodu niedostatków infrastruktury i gospodarki niedoboru $)^{10}$.

Celem artykułu jest odpowiedź na pytanie o wpływ pracy zawodowej kobiet na ich pozycję $\mathrm{w}$ małżeństwie. Jaką rolę odgrywała praca dla życia rodzinnego? Czy i w jaki sposób praca zawodowa kobiet zmieniła relacje płci w małżeństwie? Czy podejmowanie pracy było związane z konfliktami w rodzinie? Problem ten był już poruszany w literaturze dotyczącej relacji płci i emancypacji kobiet w państwowym socjalizmie, jednak raczej marginalnie.

Artykuł oparty jest na analizie narracji osobistych - oryginalnych pamiętników konkursowych. Sięgnięcie po egodokumenty ${ }^{11}$ pozwala na konfrontację dyskursów publicznych o pracy kobiet i rodzinie, znanych przynajmniej częściowo $\mathrm{z}$ istniejących opracowań, $\mathrm{z}$ doświadczeniem konkretnych małżeństw, żon i mężów. Pamiętniki dają wgląd w mikrokosmosy małżeńskie, dostarczając pewnych obiektywnych danych (np. na temat zarobków, warunków materialnych i mieszkaniowych, decyzji dotyczących pracy czy wychowania dzieci) oraz subiektywne interpretacje własnej sytuacji w kontekście aspiracji i rozumienia ról płci. Narracje osobiste pozwalają lepiej zrozumieć miejsce i znaczenie pracy zawodowej kobiet dla relacji wewnątrz rodziny. Dla ich scharakteryzowania i zrozumienia ważne jest nie tylko odtworzenie obiektywnych uwarunkowań i przyjrzenie się relacjom władzy w małżeństwie. Równie istotne są wyobrażenia autorów na temat tych relacji i proces nadawania sensu wybieranemu modelowi małżeństwa i rodziny. To, czy kobieta podejmowała pracę zawodową i ile zarabiała, musi zostać skonfrontowane z tym, czy praca ta była postrzegana jako zmieniająca jej pozycję. Tak interpretowane egodokumenty są zarówno odbiciem praktyk, jak i wyrazem mentalności autorów.

Narracje osobiste są często wykorzystywane w historiografii płci kulturowej (gender history). „Narracje osobiste kobiet - jak piszą autorki opracowania na ten temat - są dobrym punktem wyjścia dla analizy relacji między jednostką a społeczeństwem w konstruowaniu płci kulturowej”" ${ }^{2}$. „Sądzimy, że narracje osobiste są szczególnie bogatymi źródłami, ponieważ - analizowane dokładnie - ukazują logikę indywidualnych przebiegów działania oraz efekty ograniczeń systemowych, w ramach których te działania mają miejsce. [...] Narracje osobiste pozwalają nam

${ }^{10}$ J. Massino, „Something old, something new.” Marital Roles and Relations in State Socialist Romania, „Journal of Women's History” 22, 2010, nr 1, s. 34-60.

${ }^{11}$ Termin egodokumenty (ego-documents) używany jest dla opisu różnych form pisarstwa osobistego, został zaproponowany przez Jacques'a Pressera i jest definiowany jako: „te dokumenty, w których 'ja' intencjonalnie bądź nie odsłania się, bądź chowa”, R. Dekker, Introduction, w: Egodocuments and History: Autobiographical Writing in Its Social Context Since the Middle Age, ed. idem, Rotterdam 2002, s. 7.

12 Interpreting Women's Lives. Feminist Theory and Personal Narratives, eds. B. Joy Webster, Personal Narratives Group, Bloomington 1989, s. 5 (przeł. N.J.). 
dostrzec życie jako wytwór jednocześnie indywidualny i społeczny"13. Mogą być także analizowane jako „struktury mające znaczenie dla narratora”. Subiektywizm doświadczeń zapośredniczonych przez opowieść nie tylko jest indywidualnym świadectwem, ale także pozwala określić obiektywnie obowiązujące normy. Choć uwagi te formułowane są $\mathrm{w}$ odniesieniu do narracji tworzonych przez kobiety i wiążą się ze szczególną atencją dla świadectw osobistych w feministycznej historiografii, sądzę, że można odnieść je także do narracji tworzonych przez mężczyzn. Moim celem w niniejszym artykule jest uwzględnienie również spojrzenia mężczyzn na pracę zawodową kobiet i relację małżeńską.

Wykorzystałam oryginalne pamiętniki pochodzące z trzech konkursów, przeprowadzonych w latach sześćdziesiątych i siedemdziesiątych, a dotyczących życia małżeńskiego. Obiektem zainteresowania redakcji ogłaszających te konkursy nie była więc praca zawodowa kobiet, co należy uznać za okoliczność ułatwiającą interpretację nadesłanych prac. Pierwszy konkurs, zatytułowany „Młodzi po ślubie”, ogłoszony w 1964 r. przez „Życie Warszawy” we współpracy z Towarzystwem Świadomego Macierzyństwa, skierowany był do młodych małżeństw (małżonków poniżej 30. roku życia). Większość autorów nadesłanych prac (zachowało się 230 oryginałów) urodziła się w latach trzydziestych XX w. ${ }^{14}$ Już w następnym roku „Życie Warszawy” ogłosiło kolejną ankietę, zatytułowaną „Mąż i żona”, nie wprowadzając żadnych ograniczeń wiekowych. W rezultacie prace konkursowe reprezentowały doświadczenia osób urodzonych w pierwszej połowie XX w., a autorzy niektórych tekstów urodzili się jeszcze w latach osiemdziesiątych i dziewięćdziesiątych wieku XIX. Dzięki temu mamy wgląd w doświadczenia małżeństw zawartych przed II wojną światową i możemy z tej perspektywy obserwować zmiany zachodzące po 1945 r. Trzeci konkurs, z którego materiały stały się podstawą artykułu, ogłoszono dekadę później, w 1974 r., w czasopiśmie „Zarzewie”; konkurs pt. „Moje małżeństwo” skierowany był głównie do młodych małżonków. Dominującą grupą autorów były osoby urodzone w latach czterdziestych i początku lat pięćdziesiątych. $\mathrm{Z}$ racji profilu tego pisma autorzy pamiętników pochodzili głównie ze wsi i mieszkali właśnie tam lub w małych miasteczkach. We wszystkich konkursach brały udział zarówno kobiety, jak i mężczyźni. Analiza objęła łącznie 437 pamiętników. Opublikowane tomy, zawierające wybrane i zredagowane pamiętniki, pomogły jedynie ustalić, w jaki sposób redakcje zmieniały oryginalny tekst, oraz ewentualnie uzupełnić kwerendę o te prace, których oryginały się nie zachowały ${ }^{15}$.

\footnotetext{
${ }^{13}$ Ibidem, s. 4.

${ }^{14}$ W 1966 r. w Warszawie opublikowano wybrane pamiętniki w tomie Młodzi po ślubie pod redakcją Mirosławy Parzyńskiej i Joanny Horodeckiej. We wstępie redaktorki informowały, że napłynęło 378 prac (zachowało się 230).

${ }^{15}$ Ibidem; Mąż i żona, wybór i oprac. M. Parzyńska, J. Horodecka, Warszawa 1968; H. Maziejuk, S. Wiechno, Moje małżeństwo. Pamiętniki, Warszawa 1975.
} 
Wybrane konkursy należy umieścić w szerszym kontekście polskiej tradycji metody biograficznej w socjologii, zapoczątkowanej w okresie międzywojennym przez Floriana Znanieckiego i kontynuowanej przez jego ucznia, Józefa Chałasińskiego. Metoda ta, oparta na zbieraniu życiorysów „,zwykłych ludzi”, po II wojnie światowej dała początek zjawisku popularnego zainteresowania pisaniem i gromadzeniem narracji pamiętnikarskich ${ }^{16}$. Bogaty dorobek powojennego pamiętnikarstwa pozwala wykorzystać pamiętniki jako źródło do badania zarówno ról społecznych, jak i życia codziennego, aspiracji, postaw i wyobrażeń ${ }^{17}$. Jak pisała Małgorzata Szpakowska, w latach sześćdziesiątych świadomość dokonujących się na oczach współczesnych zmian społecznych i obyczajowych zaowocowała zainteresowaniem także życiem prywatnym, co sprawiło, że pośród dziesiątek konkursów znalazło się też wiele dotyczących życia rodzinnego i codziennego ${ }^{18}$. Ogłoszono ich w latach sześćdziesiątych i siedemdziesiątych niemal dwadzieścia, zachowała się jednak tylko część oryginalnych materiałów.

\section{Małżeństwo i praca zawodowa kobiet}

Na wstępie konieczne jest scharakteryzowanie zmian zachodzących w instytucji małżeństwa oraz pracy zawodowej kobiet w Polsce po II wojnie światowej. Już w 1945 r. wydano dekrety wprowadzające małżeństwa cywilne i rozwody. Prawo małżeńskie zostało ujednolicone na terenie całego kraju ( $w$ dwudziestoleciu międzywojennym funkcjonowały jeszcze przepisy państw zaborców). Wprowadzony w 1950 r. kodeks rodzinny ustanawiał równość małżeńską. Małżonkowie mieli równe prawa i równe obowiązki ${ }^{19}$. Pomimo tego, że - jak zauważyła Barbara Klich-Kluczewska - wprowadzenie tych zmian nie było poprzedzone debatą publiczną ${ }^{20}$, nowy stan prawny wpływał na ewolucję wyobrażeń o samej instytucji małżeństwa. Ślub cywilny stał się wymogiem, zaś równość mężczyzn i kobiet w związku małżeńskim była podkreślana zarówno $\mathrm{w}$ propagandzie, jak i w narracjach poradnikowych dotyczących małżeństwa, publikowanych od lat pięćdziesiątych do osiemdziesiątych ${ }^{21}$.

${ }^{16}$ K. Lebow, Autobiography as Complaint: Polish Social Memoir Between the Two World Wars, „Laboratorium. Russian Review of Social Research” 6, 2014, nr 3, s. 13-26; K. Kosiński, Pamiętnikarstwo konkursowe jako źródło historyczne, „Polska 1944/45-1989. Studia i Materiały” 6, 2004, s. 133-145; F. Jakubczak, Pót wieku pamiętnikarstwa polskiego, „Pamiętnikarstwo Polskie” 1972, nr 1, s. 133-145.

${ }^{17}$ K. Kosiński, op. cit., s. 138.

${ }^{18}$ M. Szpakowska, Chcieć i mieć. Samowiedza obyczajowa w Polsce czasu przemian, Warszawa 2003, s. 23-24.

${ }^{19}$ P. Fiedorczyk, Unifikacja i kodyfikacja prawa rodzinnego w Polsce (1945-1964), Białystok 2014.

${ }^{20}$ B. Klich-Kluczewska, Rodzina, tabu..., s. 133.

${ }^{21}$ N. Jarska, Między równościa a różnica płci. Poradniki życia małżeńskiego w PRL, w: W kręgu kultury PRL. Poradnictwo, red. D. Skotarczak, K. Bittner, Poznań 2018, s. 291-305. 
Artykuł 23 kodeksu rodzinnego obowiązującego od 1964 r. głosił, że małżonkowie mają równe prawa i obowiązki, zaś artykuł 27 wskazywał na obowiązek „zaspokajania potrzeb rodziny”, który „może polegać także, w całości lub w części, na osobistych staraniach o wychowanie dzieci i na pracy we wspólnym gospodarstwie domowym". Kodeks, podkreślając równość obowiązków, przewidywał więc model rodziny oparty na podziale ról między małżonków, co w praktyce sprowadzało się do rezygnacji przez kobiety z pracy poza domem ${ }^{22}$.

Jak zauważa Barbara Klich-Kluczewska, w okresie powojennym zmniejszyła się rola rodziców $\mathrm{w}$ doborze małżeńskim, a ten zaczął w większym stopniu zależeć od wykształcenia niż od pochodzenia społecznego ${ }^{23}$. Zmiany społeczne wpłynęły na zmianę oczekiwań wobec małżeństwa. Według badań z początku lat sześćdziesiątych młode pokolenie (ludzie w wieku 18-35 lat) widziało małżeństwo jako sposób osiągnięcia oczekiwanego poziomu materialnego, zaspokojenia potrzeb emocjonalnych i seksualnych oraz więź intelektualną, podczas gdy starsze pokolenie respondentów postrzegało je jako zawierane w celu posiadania dzieci oraz wsparcia i opieki. Socjolożka Barbara Łobodzińska przypisywała te zmiany procesom indywidualizacji ${ }^{24}$.

Rozwody były rzadkością, także w porównaniu z innymi krajami regionu ${ }^{25}$. Dopiero w latach siedemdziesiątych statystyki rozwodów poszły wyraźnie w górę. Charakterystyczne dla całego okresu PRL było podkreślanie w dyskursie publicznym i nakierowanie polityki państwa na trwałość małżeństwa. Jakkolwiek propagowano nowoczesną, zreformowaną, „,socjalistyczną” wersję związku małżeńskiego, opartego na równości i zdemokratyzowanego, rozpad małżeństw był postrzegany jako zagrożenie dla porządku społecznego. Małżeństwu i rodzinie przypisywano rolę kluczową nie tylko jako formie samorealizacji i osiągnięcia szczęścia osobistego, lecz także, a może przede wszystkim, jako instytucji mającej znaczenie dla kolektywu - społeczeństwa i państwa ${ }^{26}$.

W dziedzinie pracy zawodowej kobiet w powojennej Polsce nastąpiły bardzo szybkie i istotne zmiany, zarówno ilościowe, jak i jakościowe (pomimo pewnego zahamowania w okresie odwilży $)^{27}$. Praca zarobkowa nie była dla kobiet nowością, jednak znacząco zmieniły się dla nich możliwości edukacji i zatrudnienia dzięki celowej polityce państwa, prowadzonej - w ogólnym zarysie - dość konsekwentnie od końca lat czterdziestych. W przedwojennej Polsce poza rolnictwem główną sferą zatrudnienia kobiet była służba domowa. Po II wojnie światowej, w związku z polityką industrializacji i aktywizacji zawodowej kobiet, głównym

\footnotetext{
${ }^{22}$ Kodeks rodzinny i opiekuńczy z dn. 25.02.1964, Dz.U. 1964, nr 9, poz. 59.

${ }^{23}$ B. Klich-Kluczewska, Przez dziurkę..., s. 110-113.

${ }^{24}$ B. Łobodzińska, Małżeństwo w mieście, Warszawa 1970, s. 208-209.

${ }^{25}$ B. Klich-Kluczewska, Rodzina, tabu..., s. 146.

${ }^{26}$ Ibidem, s. 133-134; N. Jarska, Modern Marriage..., s. 469.

${ }^{27}$ M. Fidelis, Women, Communism..., passim.
} 
miejscem zatrudnienia stały się przemysł i usługi (te drugie szczególnie po 1956 r.). W latach 1948-1956 liczba zatrudnionych kobiet zwiększyła się mniej więcej o milion (osiągając blisko $2 \mathrm{mln}$ ), co oznaczało stuprocentowy wzrost. Po $1956 \mathrm{r}$. tempo wzrostu zmniejszyło się, jednak lata sześćdziesiąte i siedemdziesiąte także przyniosły istotne zmiany. W 1975 r. pracowało już blisko 5 mln kobiet. Ich udział wśród pracowników poza rolnictwem wzrósł z ok. 30 do $50 \%$ w 1980 r.

Ważnym procesem, szczególnie $\mathrm{w}$ kontekście rozważań nad wpływem pracy zawodowej na relacje $\mathrm{w}$ małżeństwie, było upowszechnianie się zatrudnienia kobiet zamężnych. Przed II wojną światową 71\% pracujących zawodowo kobiet stanowiły panny. W 1960 r. mężatki stanowiły już 55\% zatrudnionych, w 1967 r. $70 \%$, w $1970-75 \%{ }^{28}$. Pracujące zawodowo kobiety były coraz lepiej wykształcone. Już w 1958 r. niemal jedna trzecia pracowników z wyższym wykształceniem to były kobiety. Jedna piąta pracownic posiadała wyższe lub średnie wykształcenie, co było wyższym odsetkiem niż w przypadku mężczyzn; znacznie mniejsza była też liczba kobiet nieposiadających żadnego wykształcenia (nieukończona szkoła podstawowa $)^{29}$. Wśród ogółu ludności danej płci wykształcenie kobiet wypadało gorzej, ale nieznacznie (wyższy odsetek osób z wykształceniem podstawowym) ${ }^{30}$. Im wyższe było wykształcenie, tym więcej kobiet pracowało - od $50 \%$ posiadaczek wykształcenia podstawowego, przez 70\% w przypadku średniego, do $90 \%$ kobiet $\mathrm{z}$ wyższym wykształceniem ${ }^{31}$. Statystyka ta, pospołu z innymi badaniami z epoki, pokazuje, że dla aktywizacji zawodowej kobiet dostęp do wykształcenia miał kluczowe znaczenie. Według badań Adama Kurzynowskiego w 1960 r. pracę kontynuowało ponad $60 \%$ pracownic fizycznych i ponad $80 \%$ umysłowych $^{32}$.

Praca zawodowa kobiet była jednak traktowana jako drugorzędna, tak dla gospodarki, jak i dla budżetu domowego. Dyskurs na temat pracy kobiet oraz polityka zatrudnienia i płac, szczególnie po 1956 r., konceptualizowały zatrudnienie kobiet jako dodatkowe, a ich pracę jako mniej wydajną. Zgodnie z dość powszechną opinią kobiety pracowały, by uzupełnić budżet domowy, „dorobić” do zarobków męskiego żywiciela, który z reguły zarabiał więcej i którego praca nadal była postrzegana jako ważniejsza. Kobiety także stały się żywicielkami, ale ich pozycja nie była tożsama z pozycją męskich żywicieli ${ }^{33}$. Płace kobiet były zasadniczo niższe niż mężczyzn; według socjolożki Janiny Waluk, badającej problem płac kobiet, większość z nich zarabiała poniżej 1500 zł, większość mężczyzn

\footnotetext{
${ }^{28}$ N. Jarska, Kobiety z marmuru..., s. 209.

${ }^{29}$ Ibidem, s. 256.

${ }^{30}$ Kobieta $w$ Polsce, Warszawa 1985, s. 10.

${ }^{31}$ Kobieta $w$ Polsce, Warszawa 1967, s. 17.

32 A. Kurzynowski, Przemiany wzorów karier zawodowych kobiet w latach 1950-1989, w: Kobieta i praca..., s. 196.

${ }^{33}$ N. Jarska, Female Breadwinners in State Socialism: The Value of Women's Work for Wages in PostStalinist Poland, „Contemporary European History” 28, 2019, nr 4, s. 469-483.
} 
zaś powyżej 1500 zł34. W 1980 r. na stanowiskach „nierobotniczych” mediana zarobków kobiet wynosiła 4001-5000 zł, podczas gdy mężczyzn - 6001-8000 zł; w przypadku robotniczych odpowiednio 3001-4000 i 6001-8000; dysproporcje te poza płcią wskazują na czynnik klasowy - upośledzenie płacowe robotnic było większe niż kobiet trudniących się tzw. pracą umysłową ${ }^{35}$.

W latach sześćdziesiątych i siedemdziesiątych prowadzono badania socjologiczne, $w$ których badacze zadawali pytanie o poziom akceptacji dla pracy zawodowej kobiet. Pierwszym takim badaniem była ankieta OBOP na reprezentatywnej próbie, wykonana w 1960 r.; wykazała ona, że zadowolonych z faktu pracy poza domem jest $72 \%$ pracownic ${ }^{36}$. W 1974 r. inne badanie OBOP wykazało, że $41 \%$ społeczeństwa zgadzało się z opinią, że „kobieta powinna uczestniczyć w życiu zawodowym $\mathrm{w}$ takim samym stopniu jak mężczyzna, a prace domowe powinny być równo dzielone między małżonków”, ale $36 \%$ sądziło, że kobiety „powinny być tylko żonami i matkami" ${ }^{37}$. Badania te pokazują akceptację dla pracy zawodowej kobiet, a jednocześnie jej ambiwalencję, szczególnie podnoszoną w kontekście ról pozazawodowych, a także preferowanego modelu rodziny ${ }^{38}$. W niektórych środowiskach, w szczególności robotniczych, ideałem rodziny pozostawał model oparty na męskim żywicielu ${ }^{39}$. Badania te jednak, koncentrując się na aspekcie ekonomicznym i pomijając skomplikowane motywacje do podejmowania pracy, tylko w niewielkim stopniu pokazują, czy i w jaki sposób praca zawodowa wpływała na pozycję kobiet w rodzinie.

\section{Praca zawodowa kobiet a relacje w małżeństwie}

Autorzy pamiętników nadesłanych na konkursy z pewnością nie stanowią reprezentatywnej grupy. W konkursach „Życia Warszawy” mamy do czynienia z nadreprezentacją osób ze średnim ( $w$ tym zawodowym) i wyższym wykształceniem; w sumie w obu konkursach stanowiły one ok. 50\% (wyższe) i 38\% (średnie, w tym zawodowe $)^{40}$; w konkursie „Moje małżeństwo” autorzy znacznie rzadziej podawali dane o wykształceniu, ale można wnioskować, że najczęściej było ono podstawowe

\footnotetext{
${ }^{34}$ J. Waluk, Płaca i praca kobiet w Polsce, Warszawa 1965, s. 29.

${ }^{35}$ Kobieta $w$ Polsce, Warszawa 1985, s. 46-49.

${ }^{36}$ Archiwum TNS OBOP, Z. Drozdek, A. Preiss-Zajdowa, Stosunek kobiet do pracy zawodowej, Warszawa 1962.

${ }^{37}$ Archiwum TNS OBOP, O sprawach kobiet - komunikat z badań, wrzesień $1974 \mathrm{r}$.

${ }^{38}$ Aż 68\% respondentek przerwałoby pracę, gdyby dochody męża całkowicie wystarczały na utrzymanie rodziny, Archiwum TNS OBOP, Z. Drozdek, A. Preiss-Zajdowa, Stosunek kobiet do pracy zawodowej, Warszawa 1962, s. 23.

39 Zob. np. Struktura robotniczej załogi w jednej z fabryk warszawskich, red. J. Piotrowski, Warszawa 1961.

${ }^{40}$ Wyliczenia własne na podstawie zachowanych materiałów oryginalnych.
} 
bądź średnie, przy czym mieszkali oni na wsi bądź w małych miasteczkach. Miejskie rodziny robotnicze są we wszystkich tych konkursach prawie nieobecne. Jeśli na podstawie tych materiałów można wnioskować na temat rodzin robotniczych, to jedynie tych lepiej wykształconych, wykwalifikowanych (techników). Wśród autorów dominował model rodziny, w którym kobieta pracowała. W konkursie „Młodzi po ślubie” $\mathrm{w} 70 \%$ rodzin żony pracowały w momencie powstawania wypowiedzi ankietowej. W przypadku ankiety „Mąż i żona”, obejmującej także starsze pokolenie, te proporcje układały się inaczej - żony pracowały w 57\% przypadków, zaś nie pracowały - w $32 \%{ }^{41}$.

Niewielki odsetek pamiętników ukazuje model „idealny” socjalistycznej emancypacji przez pracę zawodową. Taki przypadek opisywał jeden $\mathrm{z}$ autorów (ur. w 1938 r.), a więc historię małżeństwa oglądamy tu oczami męża. Relacjonował on: „Po dyplomie - męska rozmowa, co dalej. Iza zdecydowała. Rysiek (ja) do pracy, a żona na studia na Politechnikę. Bardzo byłem zły, że tak to się układa, ale nie było rady. [...] Pracę w domu Iza rozłożyła następująco: ja nie - bo dyplom, ona też nie, bo studia i praca w prywatnym warsztacie, wobec tego dochodząca Pani do sprzątania, prania i gotowania - za 600 zł [...]. Wreszcie w 4. roku małżeństwa w pracy jest szansa dostania mieszkania, ale "potrzebne jest» dziecko, żeby mieć pewność, że się dostanie, i tak dla mieszkania - postanowiliśmy zostać rodzicami. [...] Wziąłem urlop - siedziałem z malcem i kułem do egzaminów, a Iza kończyła letnią sesję. Potem całe lato siedziała z malcem $\mathrm{w}$ domu, a na jesieni - Piotr do żłobka tygodniowego, a my wszyscy znów w kierat pracy. [...] Pracujemy razem w zakładzie - żona jako inżynier, ja jako technik i student V roku (wreszcie w styczniu dostaję dyplom). W lutym dostaję awans, zarabiam teraz 3000, ona 2800. [...] W pracy żona jest lubiana przez ludzi, przyjęto ją jak swoją i chociaż baba-inżynier, i to w czysto męskiej specjalności, umie sobie poradzić" ${ }^{2}$.

W chwili gdy pisał pamiętnik na konkurs (1964 r.), ich status zawodowy i materialny był w zasadzie równy. Do tego dzielili prace domowe. Małżeństwo autora, choć borykające się z problemami mieszkaniowymi, jak ówcześnie niemal każda młoda para, mogło uchodzić za nowoczesne, a kobieta za wyemancypowaną: pracującą zawodowo w pracy wysoce wykwalifikowanej i nieobarczoną nadmiernie obowiązkami domowymi; narodziny dziecka nie spowodowały u niej przerwy w karierze. Co jednak istotne, żona pochodziła z rodziny inteligenckiej, małżonek zaś miał pochodzenie robotnicze. Na tle innych materiałów pamiętnikarskich widać, że była to sytuacja wyjątkowa. Inteligenckie pochodzenie wywierało istotny wpływ na podejście kobiet do pracy zawodowej, być może miało też

\footnotetext{
${ }^{41}$ Wyliczenia własne na podstawie zachowanych materiałów oryginalnych.

${ }^{42}$ Wszystkie analizowane pamiętniki pochodzą z zasobu Archiwum Akt Nowych (AAN), z zespołu „Towarzystwo Pamiętnikarstwa Polskiego” (TPP). W kolejnych przypisach podaję nazwę konkursu i sygnaturę. Młodzi po ślubie, sygn. 10610.
} 
znaczenie w tworzeniu hierarchii; w tym związku to żona podejmowała istotne decyzje dotyczące podziału obowiązków bądź małżonkowie decydowali wspólnie.

Pamiętniki jednak generalnie potwierdzają drugorzędność pracy zawodowej kobiet z punktu widzenia ekonomicznego. W konkursie „Młodzi po ślubie” autorzy podawali wysokość swoich i małżonka zarobków; w przytłaczającej większości przypadków kobiety zarabiały mniej niż ich mężowie, a różnice te były nieraz znaczne. Na przykład 30-letni inżynier chemik zarabiał 2100 zł, zaś jego żona - nauczycielka po Studium Nauczycielskim - 1200 zł. Małżeństwo dwojga techników (on - mechanik, ona - wykształcenie średnie ekonomiczne) miało budżet domowy składający się z jego bardzo wysokiej pensji 4000 zł i jej ponad trzy razy niższej. W małżeństwie konduktora i nauczycielki on przynosił do domu 2300 zł, ona - jedynie 1100. Zdarzały się małżeństwa, które zaczynały od podobnego poziomu zarobków - zaraz po skończeniu szkoły czy studiów, z biegiem lat jednak dysproporcje się pojawiały bądź pogłębiały. Taki stan rzeczy ograniczał możliwe scenariusze; rezygnacja z pracy mężczyzny, choćby z powodów ekonomicznych, nie wchodziła w grę. Jego praca była zawsze ważniejsza.

Pamiętniki pokazują częste zjawisko nieciągłości pracy kobiet. Autorki bądź żony autorów pamiętników rezygnowały z pracy najczęściej z powodu konieczności zajęcia się małymi dziećmi, by potem znowu ją podjąć; część kobiet nie pracowała, gdyż nie mogła znaleźć odpowiedniej pracy.

W rodzinach o niższym wykształceniu praca kobiet często traktowana była jako dodatek, z którego można było zrezygnować, gdy pozwalała na to sytuacja finansowa. Tokarz, ożeniony z fryzjerką, stwierdzał, że jego pensja (2500 zł) im „wystarcza”, więc żona odeszła z pracy ${ }^{43}$. Urzędnik ze średnim wykształceniem zawodowym - co uważał za swoje największe osiągnięcie, mąż robotnicy (ślub w 1958 r.) - tak opisywał sytuację finansową swojej rodziny: „Żona w pierwszych latach po ślubie nie pracowała. Nie miała też specjalnego przygotowania do pracy. Szkoła podstawowa i przerwana nauka w technikum gastronomicznym nie dawała jej zawodu. Niemniej było nam dobrze. [...] W tym czasie urodziła się druga córka. [...] Żona już pracuje, zarabiamy miesięcznie 3200 zł. Umeblowaliśmy mieszkanie, na raty kupiliśmy telewizor. W kuchni graty po teściu służą nam jeszcze, chcielibyśmy jednak mieć swoje nowe. Na razie nic z tego, ledwie wiążemy koniec z końcem"44.

W obu przypadkach praca kobiet była koniecznością i rozważano ją w kontekście aktualnych aspiracji konsumpcyjnych.

Jednocześnie praca kobiet, choć drugorzędna, była jednak istotna dla budżetu domowego. Gdy okoliczności skłaniały kobiety do decyzji o rezygnacji z pracy, zwykle mężowie musieli brać dodatkowe prace, by załatać budżet domowy.

\footnotetext{
${ }^{43}$ Mąż i żona, sygn. 10391.

${ }^{44}$ Młodzi po ślubie, sygn. 10604.
} 
Autorka pamiętnika w konkursie „Młodzi po ślubie”, urodzona w 1924 r., po ślubie (1949 r.) pracę rzucała dwukrotnie. Po wojnie i ukończeniu studiów rozpoczęła pracę w banku, w której stopniowo awansowała. W 1952 r. po urodzeniu córki zdecydowała się pozostać w domu, gdyż dzieckiem chciała się zająć osobiście; mąż jej musiał wziąć dodatkowe pół etatu. „Ze swojej pracy zawodowej zrezygnowałam bez trudu. [...] Nasz budżet nie wytrzymywał naporu bieżących potrzeb. Mąż już od roku zaangażowany był w pracę naukową [...]. Trzeba mu było trochę ulżyć. Ponadto dziecko podrosło i nie wymagało mojej osobistej obecności co dawniej. Postanowiłam pójść do pracy. Znalazłam ją w poważnym przedsiębiorstwie, usytuowanym naprzeciwko domu". Rodzina zatrudniła gosposię, jednak wkrótce autorka pamiętnika zaszła w drugą ciążę i po raz drugi zrezygnowała z pracy; gosposia musiała odejść, zaś mąż ponownie podjął dodatkową pracę na pół etatu ${ }^{45}$. Materiał pamiętnikarski potwierdza też tezę, formułowaną już przez kilkoro autorów, że zarobki kobiet były traktowane jako te przeznaczone na podwyższenie statusu materialnego, sfinansowanie dóbr typu meble albo sprzęt dla domu. Cytat z pamiętnika autorki, która za mąż wyszła w 1957 r. i z początku „harowała” wraz $\mathrm{z}$ mężem w fabryce mebli, następnie zajmowała się dziećmi, świadczy o tym dobitnie: „po kilku latach mąż zapragnął kupić samochód i znowu poszłam do pracy”46.

Autorzy pamiętników rzadziej rozumieli pracę kobiet jako akt niezależności ekonomicznej. Jedna $\mathrm{z}$ autorek, bardzo zadowolona ze swojego małżeństwa („mój mąż jest najwspanialszym na świecie mężczyzną. Na każdym kroku okazuje mi tyle serca, delikatności i zainteresowania” - pisała), zauważała: „kompletnie brak mi samodzielności, jestem od niego całkowicie zależna, gdyż nie pracuję zawodowo ze względu na stan zdrowia" ${ }^{47}$. Zarobki kobiety autorzy pamiętników postrzegali jako wkład w budżet domowy, nie jako jej własne pieniądze (podobnie jak zarobki mężczyzn, tradycyjnych żywicieli rodziny). Aspekt ekonomiczny był $\mathrm{z}$ reguły przedstawiany jako negatywna strona pracy kobiet, która przecież - zgodnie z propagandą - miała być raczej drogą do emancypacji ${ }^{48}$. Znamienne jest, że o niezależności ekonomicznej pisały prawie wyłącznie te autorki pamiętników, które doświadczyły przemocy w małżeństwie. Dla nich praca była albo drogą, która pozwalała im wyjść z patologicznych i niechcianych relacji, albo przynajmniej - jeśli na rozwód się nie decydowały - uzyskać samodzielność i być $\mathrm{w}$ stanie utrzymać dzieci. Jedna $\mathrm{z}$ autorek opisywała swoje perypetie małżeńskie, które w końcu doprowadziły ją do rozwodu: „Ja, obarczona wychowaniem dziecka, nie miałam czasu na rozrywki, na jakie on mógł sobie pozwolić. Więcej czasu spędzał poza domem, wracał często pijany, awantury, kłótnie [...]. Miałam dowody zdrady, szczycił się powodzeniem wśród kobiet. [...] Byłam dla niego jako

\footnotetext{
${ }^{45}$ Młodzi po ślubie, sygn. 10612.

${ }^{46}$ Moje małżeństwo, sygn. 9938.

${ }^{47}$ Mąż i żona, sygn. 10392.

${ }^{48}$ N. Jarska, Female Breadwinners..., s. 475-476.
} 
służąca, nie jako żona i matka dziecka”. Mąż ją opuścił i została „bez środków do życia”. Po dwóch latach pojawił się znowu, by po pół roku „po kryjomu” znowu opuścić rodzinę. „Znów zostaję z dzieckiem, tylko to już inna sprawa, mam pracę, jestem niezależna od niego" - podsumowywała autorka ${ }^{49}$.

Choć większość oryginalnych prac konkursowych opisuje model rodziny, w którym kobieta pracuje zawodowo (mimo ewentualnych okresowych przerw), pamiętniki są też świadectwem utrzymującego się zjawiska zabraniania kobietom pracy przez mężów. Dowodzi ono trwałości przywiązania do modelu rodziny zachowującej sztywny podział pracy ze względu na płeć (gender division of labour): mężczyźni są żywicielami, kobiety zajmują się pracą domową, a także do roli męża jako głowy rodziny, podejmującej kluczowe decyzje. Być może zjawisko to było echem dawnego prawa małżeńskiego, wedle którego na pracę kobiety musiał wyrazić zgodę mąż. Mieszkanka Białej Podlaskiej, która wniosła o rozwód ze swoim mężem poślubionym w 1952 r., wspominała: „Mąż zabronił pracować, mówiąc, że sam potrafi utrzymać rodzinę". Po kilku latach od ślubu małżonek autorki zacząć pić i zdradzać ją. „Gdybym jeszcze raz miała zacząć życie od nowa, uczyłabym się i jeszcze raz uczyła, by nie być zależną materialnie od nikogo. Dziś pracy biurowej otrzymać nie mogę, fizycznie pracować też nie mogę" ${ }^{0}$. W narracji tej widać, że mężowski zakaz mógł trwale osłabiać pozycję żony. „Nie pozwalałem jej myśleć o pójściu do pracy" - pisał jeden $\mathrm{z}$ autorów; jak twierdził, powodem zakazu była zazdrość ${ }^{51}$. Część autorek, które doświadczyły presji ze strony mężów na porzucenie pracy, nie uległa i wbrew zdaniu męża nie zwolniła się. Według wspomnianej ankiety OBOP z 1960 r. aż 38,5\% pracujących i zadowolonych z tego faktu kobiet twierdziło, że ich mężowie są tej pracy niechętni ${ }^{52}$.

Poza funkcją ekonomiczną pracy autorzy odwoływali się do równości rozumianej jako równy status społeczny związany z wykształceniem i pracą zawodową. Kobiety argumentowały, że uczą się i pracują, by nie być „gorsze” od mężów. Mieszkanka wsi, której początek małżeństwa był burzliwy, ale dość typowy - bardzo młodo zaszła w ciążę i wyszła za mąż, tłumaczyła swój upór w zdobywaniu wykształcenia: „Nie chcąc być gorsza od męża, kontynuuję naukę w zaocznym technikum [...] uważam, że każda kobieta powinna pracować zawodowo" ${ }^{\prime 53}$. Autor pamiętnika (ur. 1920), który poślubił swoją żonę podczas okupacji, twierdził: ,inaczej wygląda sprawa, gdy żona pójdzie do pracy, usamodzielni się, wejdzie w otoczenie, które pozwoli jej spojrzeć trzeźwo na świat" ${ }^{\text {. }}$. Dążenie kobiet do zdobycia

\footnotetext{
${ }^{49}$ Mąż i żona, sygn. 10383.

${ }^{50}$ Mąż i żona, sygn. 10381.

${ }^{51}$ Młodzi po ślubie, sygn. 10606.

${ }^{52}$ Archiwum TNS OBOP, Z. Drozdek, A. Preiss-Zajdowa, Stosunek kobiet do pracy zawodowej, Warszawa 1962, s. 9.

${ }^{53}$ Moje małżeństwo, sygn. 9938.

${ }^{54}$ Mąż i żona, sygn. 10389.
} 
wykształcenia rodziło napięcia, kiedy mężowie obawiali się utraty prestiżu z powodu osiągnięcia wyższego statusu przez ich żony. Przykłady te stanowią jeszcze jeden dowód na wpływ pozycji poza rodziną na relacje wewnątrz niej. Wykształcenie i zawód służyły, zarówno mężczyznom, jak i kobietom, do budowania swojego statusu. Równość postrzegana była przez pryzmat dyplomów i pozycji zawodowej.

Dlatego wykształcenie było szczególnie ważne. Przytoczony na wstępie przykład inżynierki pokazuje, że niektórzy mężczyźni wspierali kształcenie się żon. Nie były to rzadkie przypadki. Trudności z pogodzeniem życia rodzinnego, $w$ tym opieki nad małym dzieckiem, ze zdobywaniem wykształcenia pojawiały się dość często, głównie z powodu wczesnego zawierania małżeństw. Autor pamiętnika, mieszkaniec Warszawy urodzony w 1936 r., opisywał, w jaki sposób wspierał żonę w uzyskaniu dyplomu: „Półtora roku przed ukończeniem studiów moja przyszła żona zaszła w ciążę. Zdecydowaliśmy się nie przerywać ciąży i jak najszybciej wziąć ślub. Postanowiłem jednak, że bezwzględnie zrobię wszystko, by przyjście dziecka na świat nie opóźniło ukończenia studiów przez moją żonę. Było to zadanie bardzo ciężkie. Musiałem się natychmiast zwolnić z zakładu, w którym pracowałem, znaleźć dla nas mieszkanie w Warszawie oraz znaleźć i rozpocząć nową pracę. Ciężko było mi opuszczać zakład, w którym praca układała mi się świetnie i z którym w znacznym stopniu wiązałem swoją przyszłość [...]. Pośpiesznie urządziliśmy wynajęty pokój i zamieszkaliśmy razem. Żona w tym czasie wykonywała pracę dyplomową [...]. Pomagałem żonie, ile mogłem w tym wyścigu z czasem. [...] Ja po powrocie z pracy zajmowałem się dzieckiem i sprawami gospodarstwa domowego, żona natomiast uczyła się" 55 .

Pielęgniarka, żona inżyniera, pisała o swoim dążeniu do skończenia studiów głównie w kontekście ekonomicznym: „Wspólnie pchamy się ku lepszemu jutru. Tak jak wszyscy młodzi, także i my rozpoczęliśmy od nie najlepszych warunków materialnych. [...] Marzymy o tym, by córka miała najlepsze dzieciństwo i młodość. [...] Najbliższe plany to moje studia, a potem samochód. Mąż stara się jak najwięcej zrobić w domu, abym zyskała czas na naukę"56.

Te i podobne przykłady, pochodzące z pamiętników zarówno kobiet, jak i mężczyzn, wskazują na zinternalizowanie modelu równościowego obecnego w dominującym dyskursie. W tych historiach dyplom żony i męża ma jednakowe znaczenie dla rodziny; pary wybierały taką strategię, która $\mathrm{z}$ jednej strony umożliwiała im założenie rodziny w dość tradycyjnej, ale powszechnej formie (ślub i narodziny dziecka), z drugiej - zaspokojenie przez oboje aspiracji edukacyjnych i ekonomicznych.

W opinii autorów pamiętników praca była dla kobiet źródłem poczucia wartości, które przekładało się na pozycję w rodzinie. „Mam więcej do powiedzenia" - pisała jedna $\mathrm{z}$ autorek, uzasadniając, dlaczego pracy nie przerwała, choć

\footnotetext{
${ }^{55}$ Młodzi po ślubie, sygn. 10606.

${ }^{56}$ Mąż i żona, sygn. 10394.
} 
z punktu widzenia ekonomicznego nie była ona konieczna ${ }^{57}$. Autorka pamiętnika przesłanego na konkurs „Moje małżeństwo” pisała o swoim konflikcie z teściową, która usiłowała przejąć kontrolę nad życiem młodego małżeństwa, zamieszkującego pod jej dachem: „Bądź co bądź ukończyłam technikum odzieżowe, jestem na stanowisku technologa, ale w oczach teściowej to nie było niczym"58. Autorka tej wypowiedzi konkursowej uważała, że należy jej się większy szacunek ze strony rodziny, ponieważ ma pozycję zawodową.

$\mathrm{W}$ dość przewrotny sposób jedna $\mathrm{z}$ autorek podsumowywała efekty emancypacji kobiet przez pracę zawodową: „Nastąpiło teraz wielkie rozluźnienie obyczajów, kobiety się usamodzielniły, muszą pracować. Dlatego jest wiele rozwodów. Jeżeli żona widzi, że nie ma żadnej pomocy od męża, woli iść sama przez życie, gdyby była zależna od męża, w takich wypadkach milczałaby [...]. Na ogół kobieta dzisiejsza jest przemęczona"59. Mimo iż autorka pamiętnika wyraźnie krytykowała pracę zawodową kobiet - jako wprowadzającą destabilizację w życiu społecznym i prowadzącą do tzw. podwójnego obciążenia, co było często powracającym wątkiem po 1955 r. - uznawała jej emancypacyjny potencjał. Kobiety zyskały możliwość decydowania o sobie, mężczyźni zaś - zgodnie z wizją autorki - nie potrafili się do nowej sytuacji dostosować. Obiektywnie rzecz biorąc, autorka stawiała zbyt daleko idącą diagnozę - statystyki, a także same pamiętniki wskazują, że na „pójście samej przez życie” kobiety nie decydowały się wówczas łatwo i często.

Powyższe uwagi prowadzą do wniosku, że praca zawodowa, szczególnie gdy wiązała się z wykształceniem i pozycją zawodową, wpływała pozytywnie na pozycję kobiet w małżeństwie, zarówno obiektywnie, jak i w ich własnej ocenie. Statusem tym mogły zachwiać czasowe przerwy w pracy oraz niższe (bądź znacznie niższe) zarobki kobiet. Pamiętniki częściowo potwierdzają też, że stosunek do pracy zawodowej kobiet różnił się w zależności od jej klasy - rozumianej przede wszystkim jako rodzaj pracy w połączeniu z poziomem wykształcenia ${ }^{60}$. Determinacja w zdobyciu wykształcenia i kontynuowaniu pracy zawodowej po przerwach wymuszonych różnymi okolicznościami cechowała głównie studentki i kobiety z wyższym wykształceniem, choć dość rozpowszechniona była również wśród kobiet $\mathrm{z}$ wykształceniem średnim. $\mathrm{W}$ tych też przypadkach praca mogła mieć wpływ na pozycję w rodzinie, jako że była potwierdzeniem statusu społecznego. Kobiety wykształcone i posiadające zawód budowały na tym również swój domowy prestiż. Kobiety o niskim poziomie wykształcenia (podstawowym) nie posiadały z reguły żadnego konkretnego zawodu. Jako że ich mężowie zazwyczaj zarabiali zbyt mało, by samodzielnie utrzymać rodzinę, one też pracowały

\footnotetext{
${ }^{57}$ Moje małżeństwo, sygn. 9938.

${ }^{58}$ Moje małżeństwo, sygn. 9938.

${ }^{59}$ Mąż i żona, sygn. 10385.

${ }^{60}$ Archiwum TNS OBOP, Z. Drozdek, A. Preiss-Zajdowa, Stosunek kobiet do pracy zawodowej, Warszawa 1962, s. 9.
} 
(przynajmniej czasowo), ale o tej pracy nie wyrażały się w kategoriach pozycji czy awansu. $\mathrm{W}$ dostępnym materiale pamiętnikarskim, jak już wspomniałam, dominują jednak autorzy lepiej wykształceni, stąd wnioskowanie o niższych klasach jest bardzo ograniczone i kwestia ta wymaga dalszych badań.

Praca zawodowa wpływała więc na zmianę statusu kobiet w małżeństwie, ale trzeba zauważyć, że sam fakt decydowania o swoim wykształceniu i podejmowaniu (bądź nie) pracy świadczy o zmianie pozycji. Pamiętniki ukazują tu różne scenariusze: kobiety decydowały same, decyzje zapadały wspólnie albo też na swoim stawiała "głowa rodziny”, czyli tradycyjnie mąż. Pojawiają się tu również wzmianki o innych praktykach, które mogą świadczyć o redefinicji hierarchii $\mathrm{w}$ małżeństwie i rodzinie.

\section{Model partnerski?}

W PRL nie doszło do rewolucji, jeśli chodzi o wykonywanie prac domowych. Były one nadal postrzegane jako domena kobiet i w większości przez kobiety wykonywane, niezależnie od pracy zawodowej; pod koniec lat sześćdziesiątych kobiety spędzały na pracy domowej od 4 do 7 godzin dziennie ${ }^{61}$. W skali europejskiej utrzymywanie się podziału pracy domowej uzależnionego od płci udowodnił Alexander Szalai, choć według jego badań mężczyźni z krajów socjalistycznych poświęcali na pracę w domu nieco więcej czasu niż mężczyźni na Zachodzie ${ }^{62}$. Jak zauważyła Katarzyna Stańczak-Wiślicz, po 1956 r. kojarzenie gospodarstwa domowego z rolą kobiet nie było podważane ${ }^{63}$. Propagowano jednak model mężczyzny, który „pomaga” w pracach domowych ${ }^{64}$.

Pamiętniki z jednej strony ukazują trwałość kulturowego powiązania prac domowych z rolą kobiety i żony, z drugiej - wyraźnie świadczą o tym, że rosły oczekiwania kobiet na pomoc ze strony mężczyzn, ale dążenie do równego podziału obowiązków wyrażali nieliczni ${ }^{65}$. Prace domowe uznawano z reguły za

${ }^{61}$ H. Strzemińska, Praca a dom w świetle badań budżetu czasu, w: Kobieta, praca, dom. Problemy pracy zawodowej kobiet $i$ rodziny współczesnej. Materiały $z$ konferencji naukowej zorganizowanej przez Zarząd Główny Ligi Kobiet w dniach 25-27 marca 1965 r., oprac. A. Kłoskowska, J. Piotrowski, Warszawa 1967, s. 380-382.

${ }^{62}$ The Use of Time: Daily Activities of Urban and Suburban Populations in Twelve Countries, ed. A. Szalai, Hague-Paris 1972, s. 583, 587.

${ }^{63}$ K. Stańczak-Wiślicz, Household as a Battleground of Modernity: Activities of the Home Economic Committee Affiliated to the League of Women (1957-80), "Acta Poloniae Historica” 115, 2017, s. 125.

${ }^{64}$ N. Jarska, Men as Husbands and Fathers in Postwar Poland (1956-1975): Towards New Masculine Identities?, „Men and Masculinities” 2020, marzec, preprint, s. 7.

${ }^{65}$ Eadem, Codzienne konflikty matżeńskie $w$ Polsce $w$ latach sześćdziesiątych i siedemdziesiątych XX wieku, w: Życie codzienne w PRL, red. T. Osiński, M. Choma-Jusińska, M. Kruszyński, LublinWarszawa 2019, s. 255-266. 
„niemęskie”. Jeśli jednak były jakieś argumenty za zaangażowaniem mężczyzn, to jednym $\mathrm{z}$ nich była $\mathrm{z}$ pewnością praca zawodowa żony. Pochodzący $\mathrm{z}$ rodziny robotniczej i kształcący się w liceum dla pracujących (z żoną, która była kelnerką, ożenił się w 1954 r.) autor pamiętnika wyjaśniał: „pomagamy sobie wzajemnie we wszystkich pracach, nawet kulinarnych, gdyż żona nadal pracuje" ${ }^{\prime 6}$. Kobiety także uzasadniały konieczność pomocy mężów faktem pracy zawodowej. Tradycyjny podział zadań wydawał się rodzajem sprawiedliwości, kiedy jednak kobiety podejmowały na stałe pracę zawodową, nie można już było mówić o wzajemności czy sprawiedliwym podziale odpowiedzialności. Pamiętnik pielęgniarki (ur. 1924, ślub w 1943 r.) pokazuje z jednej strony wpływ pracy na pozycję, z drugiej - na zaangażowanie męża, na którego autorka się skarżyła z powodu pijaństwa i zdrad: „powrót do pracy zawodowej i pełna samodzielność dają mi siłę, aby przetrwać te złe chwile. Moja praca - na różne zmiany - zmusza męża do większego zaangażowania się w sprawy domowe" ${ }^{67}$. W tym wypadku rolę odegrał aspekt praktyczny - praca w systemie zmianowym.

Podział obowiązków w domu wynikał także z wyobrażeń o równouprawnieniu i partnerstwie. Jak zauważyła Małgorzata Szpakowska, podział obowiązków domowych był najważniejszym wyznacznikiem partnerstwa w rodzinie ${ }^{68}$. Lektura pamiętników mężczyzn przekonuje, że jeśli angażowali się oni w prace domowe (wedle własnego mniemania), gest ten rozumieli jako jeden $\mathrm{z}$ aspektów dzielenia różnych sfer wspólnego życia. W małżeństwach zawieranych przez pokolenie urodzone w latach trzydziestych model "towarzyszący” (companionate marriage) zyskiwał na popularności. Stosowanie terminu companionate marriage przez historyków jest krytykowane za wielość znaczeń, wynikającą z różnego rozumienia i definiowania tego pojęcia przez cały XX w. ${ }^{69}$ Uważam jednak, że jest on - jeśli dobrze zdefiniowany - pomocny w zrozumieniu i określeniu tego, w jaki sposób wielu autorów pamiętników konkursowych w Polsce w latach sześćdziesiątych i siedemdziesiątych określało istotę swoich małżeństw. Nawet w warstwie językowej autorzy odwoływali się często do wzajemności, towarzyszenia czy dzielenia. Małżeństwo „towarzyszące”/,koleżeńskie” odnosi się przede wszystkim do typu relacji między małżonkami, opartej na okazywaniu uczuć, zwierzaniu się sobie, wspólnym podejmowaniu decyzji ${ }^{70}$. Do tej definicji dodać można także dzielenie odpowiedzialności, zainteresowań, czasu wolnego. Co istotne, w modelu tym zmieniały się relacje władzy, wzajemność wymagała zrezygnowania z dominacji.

\footnotetext{
${ }^{66}$ Młodzi po ślubie, sygn. 10613 (ten pamiętnik opublikowano w tomie).

${ }^{67}$ Mąż i żona, sygn. 10393.

${ }^{68}$ M. Szpakowska, op. cit., s. 45.

${ }^{69}$ K. Fisher, Marriage and Companionate Ideas Since 1700, w: The Routledge History of Sex and the Body: 1500 to the Present, eds. S. Toulalan, K. Fisher, London 2013, s. 330.

${ }^{70}$ Ibidem, s. 331.
} 
Takie rozumienie małżeństwa wymagało także zmiany w podejściu do prac domowych. Podział obowiązków między małżonkami wymagał negocjacji i był jedną ze sfer wspólnych ustaleń. Jak deklarował jeden z autorów (wykształcenie średnie, ślub w 1957 r.): „Byłem przyzwyczajony do pracy domowej jeszcze z okresu kawalerskiego. Oprócz tego zawarliśmy z żoną niepisaną umowę, że wszelkie prace domowe będziemy wykonywali wspólnie, bez specjalnego podziału [...]. Żona jako matka zajmuje się dziećmi i wszelką przy nich pracą. Mnie przypadły raczej prace męskie, a więc uzupełnianie zapasu węgla i drzewa oraz wszelkie naprawy urządzeń [...]. Ponadto pomagam przy sprzątaniu mieszkania (moja specjalność - odkurzanie elektroluksem). Obowiązkowo pomagam przy myciu naczyń lub przy niektórych pracach kulinarnych"71.

Autor pamiętnika twierdził, że zamienił swoje hobby - grę w szachy - na prace domowe. Gest taki oznaczał wyraźne przesunięcie w realizacji męskości - od męskiego hobby ku „niemęskiej” pracy domowej. Inny autor, mąż nauczycielki, relacjonował: „Żona musiała zrezygnować z pracy, bo nie ma przedszkola; pracę domową dzielimy tak jak kiedyś, gdy żona pracowała”72. „Pomagam żonie, bo małżonkowie powinni sobie pomagać"73 - przekonywał inny autor, urodzony w 1934 r. Wzajemna pomoc w różnych sferach wspólnego życia stopniowo zastępowała sztywne podziały. W zmieniającym się pojmowaniu małżeństwa praca zawodowa żony nie była konieczna - nie wymuszała automatycznie pomocy męża w pracach domowych, a jej ustanie nie oznaczało powrotu do tradycyjnego podziału. Jedna $\mathrm{z}$ autorek, które świadomie i z przekonaniem wybrały rolę gospodyni domowej, żona inżyniera (ślub w 1957 r.), także wskazywała na rodzaj partnerskich relacji w małżeństwie: „Mąż czasami pomaga mi w ciężkich pracach domowych, wspólnie wychowujemy dzieci, razem decydujemy o sprawach finansowych"74. Model "towarzyszący” wpływał na poszerzanie się przestrzeni wspólnego działania i decydowania, ale mógł istnieć - w pojęciu autorów - także $\mathrm{w}$ ramach modelu rodziny opartej na męskim żywicielu.

Czy upowszechniający się po II wojnie światowej model „towarzyszący”, oparty na dzieleniu odpowiedzialności i czasu w różnych sferach wspólnego życia, model, w którym role kobiet i mężczyzn były negocjowane w stronę większej elastyczności i w którym zmieniały się relacje władzy na korzyść kobiet, można przypisać tylko wąskim kręgom społecznym? Uznawanie prawa kobiet do rozwoju zawodowego i samorealizacji było obecne już przed II wojną światową

\footnotetext{
${ }^{71}$ Młodzi po ślubie, sygn. 10613.

${ }^{72}$ Młodzi po ślubie, sygn. 10618.

${ }^{73}$ Młodzi po ślubie, sygn. 10621.

${ }^{74}$ Mąż i żona, sygn. 10386.

${ }^{75}$ Pamiętniki starszych pokoleń (osób urodzonych przed 1920 r.) pokazują zdecydowanie większe przywiązanie do tradycyjnego podziału ról (mężczyzna jako żywiciel, kobieta zajmująca się domem).
} 
w środowiskach inteligenckich. Jak pisała Katarzyna Sierakowska, w dwudziestoleciu inteligentki kształciły się i uzyskiwały niezależność ekonomiczną, często kontynuowały pracę zawodową mimo zamążpójścia ${ }^{76}$. Upowszechniał się też model „małżeństwa koleżeńskiego” i małżeństwa partnerskiego (w którym partnerstwo dotyczyło życia intelektualnego i obyczajów), choć - jak zauważa badaczka - napotykał on opory. W praktyce inteligencki ideał wypadał blado, ponieważ większość inteligentek rezygnowała $\mathrm{z}$ pracy po zamążpójściu lub urodzeniu dziecka ${ }^{77}$. Prawdopodobnie po II wojnie światowej kobiety zdobywające wyższe wykształcenie także poruszały się w ramach tej tradycji. Dla powojennych przedstawicielek inteligencji praca stała się oczywistością. Nie można jednak nie docenić wpływu powojennej propagandy i polityki promującej podejmowanie pracy zawodowej przez kobiety, kształcenie się, zdobywanie zawodu i przedefiniowanie roli pracy kobiet niższych klas - z przymusu ekonomicznego do równego statusu z mężczyzną. Analizowane materiały pamiętnikarskie świadczą o ekspansji zarówno modelu „towarzyszącego", jak i pozytywnej waloryzacji pracy zawodowej mężatek również pośród osób ze średnim wykształceniem (choć postawy bardziej tradycyjne również występowały). Jak pokazują wspomniane badania socjologiczne, w środowiskach robotniczych (ściślej mówiąc - tam, gdzie mężczyzna był robotnikiem), szczególnie wykwalifikowanych, praca kobiet nadal była traktowana raczej jako objaw degradacji społecznej, ewentualnie dodatkowy dochód $^{78}$. Materiały pamiętnikarskie dostarczają zbyt mało świadectw, by tę tezę podważyć, jednak pojawiały się wśród nich narracje pokazujące, że nowe wyobrażenia o pracy zawodowej i jej roli w małżeństwie, będące połączeniem starych inteligenckich wyobrażeń i nowych socjalistycznych haseł, popularyzowały się w szerszych kręgach społecznych.

Ciekawy przykład stanowi pamiętnik (a ściślej dziennik) mieszkanki wsi, urodzonej w 1951 r. Autorka zajmowała się stolarką, mąż (poślubiony w 1971 r.) był kierowcą. Dzieje tego małżeństwa były burzliwe. On „rozpił się”, gdy stracili ciążę na samym początku małżeństwa. Ona jednak - jak twierdzi - „uratowała związek” i sprawiła, że mąż przestał pić. „Czesław odstąpił dziś od wszelkich zasad i mimo moich protestów wziął się za prasowanie dziecięcych fatałaszków, choć bardzo nie lubi tego zajęcia i jest wczesne niedzielne popołudnie. Tłumaczył mi, że ponieważ teraz bardzo mało może mi pomóc w dzień roboczy, więc niech choć dziś wyręczy mnie w robocie. [...] Rozumie męczące «babskie» zajęcia. I nigdy nie wymiguje się w pomocy w ich wykonaniu. Czesław ma swoje ulubione zajęcia

\footnotetext{
${ }^{76}$ K. Sierakowska, Rodzice, dzieci, dziadkowie. Wielkomiejska rodzina inteligencka 1918-1939, Warszawa 2003.

${ }^{77}$ Ibidem.

${ }^{78}$ Choć zdarzały się wyjątki, jak np. robotnica, której słowa cytuje Janina Waluk: „Kobiety powinny pracować zawodowo, bo mężczyźni inaczej wtedy do nich podchodzą", J. Waluk, Postawy kobiet wobec własnej pracy zawodowej, „Studia Socjologiczne” 1963, nr 3, s. 142.
} 
domowe, odkąd zakupiliśmy pralkę, pranie stało się niemal jego specjalnością. [...] To [prace domowe] to jest ten odcinek na naszej drodze małżeńskiej, gdzie zawsze panował ład i porządek. Czemu to zawdzięczamy? Wzajemnemu wyrozumieniu dla siebie i ogromnej tolerancji dla chęci i predyspozycji w danym dniu do dzielenia się obowiązkami domowymi, małżeńskimi i rodzicielskimi. [...] Teraz, gdy wiemy, co należy dać drugiemu i czego oczekujemy od siebie - staliśmy się kumpelskim małżeństwem. Nie rozdzielamy prac na babskie, męskie. Są one po prostu nasze, wspólne. [...] Zawsze miałam ogromne plany związane z moim wykształceniem. [...] Właściwie już dziś mogłabym rozpocząć uzupełnianie swojego wykształcenia, ale rozumiem, że teraz mam przede wszystkim obowiązek względem rodziny [...]. Gdy urodził się syn, mąż chciał, abym przerwała pracę, a zajęła się domem i dzieckiem. Skrycie sama o tym marzyłam, ale przecież nie mogłam sobie na to pozwolić. Zrezygnować $\mathrm{z}$ drugiej pensji to by znaczyło jeszcze na wiele dodatkowych lat przedłużyć okres dorabiania się"79.

Pamiętnik ten łączy kilka wątków powyższej analizy. Jego autorka nie reprezentowała jednak miejskiej „klasy średniej” - nie miała nawet średniego wykształcenia i trudniła się pracą fizyczną. W jej biografii pojawia się zarówno dążenie do realizacji modelu „towarzyszącego” („kumpelskiego”), jak i do zdobycia lepszej pozycji zawodowej. Podejście autorki do wykształcenia i pracy zawodowej było skomplikowane i ukazuje konflikt ról: chciała zdobyć lepsze wykształcenie, ale pierwszeństwo przyznawała opiece nad dzieckiem; pracę chciała przerwać, ale ostatecznie się na to nie zdecydowała z powodów ekonomicznych. Pamiętnik stanowi ciekawy przykład przenikania się różnych modeli, pokazując też ekspansję wzorców w Polsce przedwojennej kojarzonych jedynie z inteligencją.

\section{Konkluzje}

Pamiętniki konkursowe pokazują wielość doświadczeń i wzorców. Próby jednoznacznego generalizowania na podstawie tych materiałów są trudne i skazane na porażkę. Narracje osobiste zawarte w pamiętnikach pozwalają jednak na wytyczenie zakresów tego, co było akceptowane czy możliwe dla autorów i ich otoczenia. Bohaterowie tych opowieści, podejmując decyzje związane ze swoim życiem małżeńskim, poruszali się w pewnych granicach, które na podstawie pamiętników możemy odtwarzać. Wzorce te nie determinowały jednak autorów, którzy - często świadomie - je łamali.

Pamiętniki pokazują ambiwalentną pozycję pracy zawodowej kobiet. Jej upowszechnienie się osłabiło rolę mężczyzny jako żywiciela, nadal jednak z reguły dominował on ekonomicznie. Praca kobiet była drugorzędna, choć im wyższe kwalifikacje, tym bardziej ceniona. W pojęciu autorów wykształcenie i praca mogły

\footnotetext{
${ }^{79}$ Moje małżeństwo, sygn. 9946.
} 
zapewnić kobietom równy status, co przekładało się na stosunki wewnątrz małżeństwa. Autorzy podkreślali głównie rolę prestiżu i statusu, rzadziej niezależności ekonomicznej, która stawała się istotna w sytuacjach skrajnych. Praca zawodowa kobiet była też dla autorów argumentem za podziałem prac domowych, choć określany był on niezmiennie jako „pomoc” męża żonie.

Jednakże praca zawodowa nie była jedynym czynnikiem zmiany relacji małżeńskich w stronę większej równości i partnerstwa. Na przykładzie stosunku do prac domowych widać, że wielką rolę odgrywało rozumienie małżeństwa w kategoriach wspólnoty opartej na wzajemności i pomocy. W ramach tego modelu, który się coraz bardziej upowszechniał, kobiety mogły zyskać lepszą pozycję. Model ten, podobnie jak praca zawodowa kobiet, był promowany przez państwo po wojnie, głównie za pośrednictwem literatury eksperckiej (w tym poradnikowej). W ten sposób oba wątki emancypacji kobiet się spotykały. Jednocześnie - co także pokazują pamiętniki - wzorce bardziej partnerskie i nieoparte na dominacji męskiego żywiciela miały swoje korzenie $\mathrm{w}$ przedwojennych ideach i praktykach.

\section{Professional Work of Women and Marriage Relations in Post-War Poland. An Analysis of Materials of Memoir Competitions Held in 1963, 1964, and 1974 (Summary)}

The purpose of the study is to answer the question about the impact made by the professional work of women on their position in marriage in post-war Poland (from the 1950s to the early 1970s). The author addresses the problem within the context of women's emancipation in state socialist countries in two dimensions: marital equality and professional activation. The article provides an analysis of ego-documents: original memoirs. They make it possible to reconstruct the contemporary social norms and their authors' opinions of genders. The analysis covers 437 memoir narratives written mainly by people representing the middle and upper social class. It shows the coexistence of various models relating to the professional work of women and marital relations. It is possible, however, based on these source materials to indicate the positive impact of women's professional career on the change in their marital status. On the other hand, the popularisation of the partnership model of marriage based on mutuality, shared responsibility, and joint decision-making, also changed the status of women in marriage.

\section{Bibliografia}

Asztalos Morell I., How to Combine Motherhood and Wage Labour: Hungarian Expert Perspectives During the 1960s, w: Gender, Equality and Difference During and After State Socialism, ed. R. Kay, New York 2007, s. 41-62

Brunnbauer U., Taylor K., Creating a "socialist way of life": family and reproduction policies in Bulgaria, 1944-1989, „Continuity and Change” 19, 2004, s. 283-312

Chojnowski A., Polska po Październiku '56. Przewodnik statystyczny po życiu rodzinnym, „Dzieje Najnowsze" 49, 2017, nr 3, s. 145-173

Dekker R., Introduction, w: Egodocuments and History. Autobiographical Writing in Its Social Context Since the Middle Age, ed. idem, Rotterdam 2002 
Fidelis M., Equality through Protection. The Politics of Women's Employment in Postwar Poland 19451956, „Slavic Review” 63, 2004, nr 2, s. 301-324

Fidelis M., Women, Communism, and Industrialization in Postwar Poland, Cambridge 2010

Fiedorczyk P., Unifikacja i kodyfikacja prawa rodzinnego w Polsce (1945-1964), Białystok 2014

Fisher K., Marriage and Companionate Ideas Since 1700, w: The Routledge History of Sex and the Body: 1500 to the Present, eds. S. Toulalan, K. Fisher, London 2013, s. 328-348

Goldman W.Z., Women at the Gates. Gender and Industry in Stalin's Russia, Cambridge 2002

Haan F. de, Women as the "motor of modern life". Women's work in Europe west and east since 1945, w: Women and Gender in Postwar Europe. From Cold War to European Union, eds. J. Regulska, B.G. Smith, London-New York 2012, s. 97-113

Haney L., From Proud Worker to Good Mother: Women, the State, and Regime Change in Hungary, „Frontiers. A Journal of Women Studies” 14, 1994, nr 3, s. 113-150

Harsch D., Revenge of the Domestic: Women, the Family, and Communism in the German Democratic Republic, Princeton 2007

Ignaciuk A., No Man's Land? Gendering Contraception in Family Planning Advice Literature in StateSocialist Poland (1950s-1980s), „Social History of Medicine” (cop.) 2019, preprint, s. 1-23

Interpreting Women's Lives. Feminist Theory and Personal Narratives, eds. B. Joy Webster, Personal Narratives Group, Bloomington 1989

Jakubczak F., Pót wieku pamiętnikarstwa polskiego, „Pamiętnikarstwo Polskie” 1972, nr 1, s. 133-145

Jarosz D., Kobiety a praca zawodowa w Polsce w latach 1944-1956 (główne problemy w świetle nowych badań źródłowych), w: Kobieta i praca. Wiek XIX i XX, red. A. Szwarc, A. Żarnowska, Warszawa 2000, s. 217-241

Jarska N., Codzienne konflikty małżeńskie $w$ Polsce $w$ latach sześćdziesiątych i siedemdziesiątych $X X$ wieku, w: Życie codzienne w PRL, red. T. Osiński, M. Choma-Jusińska, M. Kruszyński, Lublin-Warszawa 2019, s. 255-266

Jarska N., Female Breadwinners in State Socialism: The Value of Women's Work for Wages in PostStalinist Poland, „Contemporary European History” 28, 2019, nr 4, s. 469-483

Jarska N., Gender and Labour in Post-War Communist Poland. Female Unemployment 1945-70, „Acta Poloniae Historica” 110, 2014, s. 49-85

Jarska N., Kobiety $z$ marmuru. Robotnice w Polsce w latach 1945-1960, Warszawa 2015

Jarska N., Men as Husbands and Fathers in Postwar Poland (1956-1975): Towards New Masculine Identities?, „Men and Masculinities” 2020, marzec, preprint

Jarska N., Między równością a różnica płci. Poradniki życia matżeńskiego $w$ PRL, w: W kręgu kultury PRL. Poradnictwo, red. D. Skotarczak, K. Bittner, Poznań 2018, s. 291-305

Jarska N., Modern Marriage and the Culture of Sexuality: Experts between the State and the Church in Poland, 1956-1970, „European History Quarterly” 43, 2019, nr 3, s. 467-490

Klich-Kluczewska B., Biopolitics and (Non-)Modernity. Population Micro-Policy, Expert Knowledge and Family in Late-Communist Poland, „Acta Poloniae Historica” 115, 2017, s. 151-174

Klich-Kluczewska B.,Przezdziurkęodklucza.Życieprywatnewpowojennym Krakowie, Warszawa 2005

Klich-Kluczewska B., Rodzina, tabu i komunizm w Polsce 1956-1989, Kraków 2015

Kobieta $w$ Polsce, Warszawa 1985

Kościańska A., Płeć, przyjemność i przemoc. Kształtowanie wiedzy eksperckiej o seksualności w Polsce, Warszawa 2014

Kosiński K., Pamiętnikarstwo konkursowe jako źródło historyczne, „Polska 1944/45-1989. Studia i Materiały" 6, 2004, s. 133-145

Kurzynowski A., Przemiany wzorów karier zawodowych kobiet w latach 1950-1989, w: Kobieta i praca. Wiek XIX $i$ XX, red. A. Szwarc, A. Żarnowska, Warszawa 2000

Lebow K., Autobiography as Complaint: Polish Social Memoir Between the Two World Wars, „Laboratorium. Russian Review of Social Research" 6, 2014, nr 3, s. 13-26 
Lebow K., Unfinished Utopia. Nowa Huta, Stalinism, and Polish Society, 1949-56, Ithaca 2013

Lišková K., Sexual Liberation, Socialist Style: Communist Czechoslovakia and the Science of Desire, 1945-1989, Cambridge 2018

Łobodzińska B., Matżeństwo w mieście, Warszawa 1970

Massino J., Constructing the Socialist Worker. Gender, Identity and Work under State Socialism in Braşov, Romania, „Aspasia. The International Yearbook of Central, Eastern, and Southeastern European Women's and Gender History" 3, 2009, s. 131-160

Massino J., „Something old, something new." Marital Roles and Relations in State Socialist Romania, „Journal of Women's History” 22, 2010, nr 1, s. 34-60

Maziejuk H., Wiechno S., Moje małżeństwo. Pamiętniki, Warszawa 1975

Mazurek M., Społeczeństwo kolejki. O doświadczeniach niedoboru 1945-1989, Warszawa 2010

Mąż i żona, oprac. M. Parzyńska, J. Horodecka, Warszawa 1968

McLellan J., Love in the Time of Communism: Intimacy and Sexuality in the GDR, Cambridge 2011

Młodzi po ślubie, oprac. M. Parzyńska, J. Horodecka, Warszawa 1996

Perkowski P., Aktywność zawodowa gospodyń domowych na łamach prasy kobiecej Polski Ludowej, w: Koniec mitu niewinności? Płeć i seksualność w socjalizacji i edukacji, red. L. Kopciewicz, E. Zierkiewicz, Warszawa 2009, s. 289-315

Perkowski P., Wedded to Welfare? Working Mothers and the Welfare State in Communist Poland, „Slavic Review” 76, 2017, nr 2, s. 455-480

Podskarbi R., Praca daje wyzwolenie. O nowej kobiecie w nowej Polsce, w: Społeczeństwo PRL. Historia. Kultura. Pamięć, t. 1: Historia, red. S. Jankowiak, D. Skotarczak, I. Skórzyńska, Poznań 2011, s. $261-269$

Sierakowska K., Rodzice, dzieci, dziadkowie. Wielkomiejska rodzina inteligencka 1918-1939, Warszawa 2003

Stańczak-Wiślicz K., Household as a Battleground of Modernity: Activities of the Home Economic Committee Affiliated to the League of Women (1957-80), „Acta Poloniae Historica” 115, 2017

Struktura robotniczej załogi w jednej z fabryk warszawskich, red. J. Piotrowski, Warszawa 1961

Strzemińska H., Praca a dom w świetle badań budżetu czasu, w: Kobieta, praca, dom. Problemy pracy zawodowej kobiet i rodziny współczesnej. Materiały z konferencji naukowej zorganizowanej przez Zarząd Główny Ligi Kobiet w dniach 25-27 marca 1965 r., oprac. A. Kłoskowska, J. Piotrowski, Warszawa 1967

Szpakowska M., Chcieć i mieć: samowiedza obyczajowa w Polsce czasu przemian, Warszawa 2003

The Use of Time: Daily Activities of Urban and Suburban Populations in Twelve Countries, ed. A. Szalai, Hague-Paris 1972

Tóth, E.Z., „My Work, My Family, My Car”: Women's Memories of Work, Consumerism, and Leisure in Socialist Hungary, w: Gender Politics and Everyday Life in State Socialist Eastern and Central Europe, eds. J. Massino, S. Penn, New York 2009, s. 33-44

Waluk J., Płaca i praca kobiet w Polsce, Warszawa 1965

Waluk J., Postawy kobiet wobec własnej pracy zawodowej, „Studia Socjologiczne” 1963, nr 3

Zimmermann S., Gender Regime and Gender Struggle in Hungarian State Socialism, „Aspasia. The International Yearbook of Central, Eastern, and Southeastern European Women's and Gender History" 4, 2010, s. 1-24

Natalia Jarska zajmuje się historią społeczną i historią kobiet w Polsce po II wojnie światowej. Autorka książki Kobiety z marmuru. Robotnice w Polsce w latach 1945-1960 (Warszawa 2015), publikowała m.in. w „Kwartalniku Historycznym”, „Acta Poloniae Historica”, „Contemporary European History”, „European History Quarterly” i „The History of the Family”.

Kontakt: njarska@ihpan.edu.pl 